\title{
A novel Pax5-binding regulatory element in the Igk locus
}

\author{
Rena Levin-Klein, Andrei Kirillov, Chaggai Rosenbluh, Howard Cedar and Yehudit Bergman* \\ Department of Developmental Biology and Cancer Research, Institute for Medical Research Israel-Canada, Hebrew University Medical School, Jerusalem, Israel
}

\author{
Edited by: \\ Ananda L. Roy, Tufts University School \\ of Medicine, USA \\ Reviewed by: \\ Michael Reth, \\ Albert-Ludwigs-University, Germany \\ James Hagman, National Jewish \\ Health, USA \\ Ranjan Sen, National Institutes of \\ Health, USA \\ *Correspondence: \\ Yehudit Bergman, Department of \\ Developmental Biology and Cancer \\ Research, Institute for Medical \\ Research Israel-Canada, Hebrew \\ University Medical School, P.O.B. \\ 12272, Ein Kerem, Jerusalem 91120 , \\ Israel \\ e-mail:yehudit.bergman@huji.ac.il
}

The Igк locus undergoes a variety of different molecular processes during B cell development, including V(D)J rearrangement and somatic hypermutations (SHM), which are influenced by cis regulatory regions (RRs) within the locus. The lgk locus includes three characterized RRs termed the intronic (iЕк), $3^{\prime} \mathrm{E} \kappa$, and Ed enhancers. We had previously noted that a region of DNA upstream of the $\mathrm{iEk}$ and matrix attachment region (MAR) was necessary for demethylation of the locus in cell culture. In this study, we further characterized this region, which we have termed Dm, for demethylation element. Pre-rearranged lgk transgenes containing a deletion of the entire Dm region, or of a Pax5-binding site within the region, fail to undergo efficient $\mathrm{CpG}$ demethylation in mature $\mathrm{B}$ cells in vivo. Furthermore, we generated mice with a deletion of the full Dm region at the endogenous Igk locus. The most prominent phenotype of these mice is reduced SHM in germinal center B cells in Peyer's patches. In conclusion, we propose the Dm element as a novel Pax5-binding cis regulatory element, which works in concert with the known enhancers, and plays a role in Igк demethylation and SHM.

Keywords: V(D)J rearrangement, DNA methylation, B cell development, Pax5, somatic hypermutation

\section{INTRODUCTION}

The $\mathrm{B}$ cell receptors (BCRs) are encoded in the mouse genome by the three immunoglobulin (Ig) loci, the IgH heavy chain locus, and the two light chain loci, Igk and Ig $\lambda$. In their germline conformations, the Ig loci do not give rise to functional proteins. It is only through a tightly regulated process of genome editing, termed $\mathrm{V}(\mathrm{D}) \mathrm{J}$ recombination, that the loci are reconfigured to allow transcription of an Ig gene in B cells. During the recombination process, the variable $(\mathrm{V})$, diversity $(\mathrm{D})$, and joining $(\mathrm{J})$ segments are cleaved by the RAG complex and joined together into one continuous segment by the DNA repair machinery (1). Each rearrangement utilizes a single V, D (in the heavy chain), and $\mathrm{J}$ segment, and each $\mathrm{B}$ cell contains one productively rearranged heavy chain and light chain. In this way, B cells give rise to the multitude of antigen recognition specificities which constitutes the adaptive immune system.

The recombination of the different loci takes place in a developmentally staggered manner, with the IgH locus undergoing VDJ recombination first in the pro-B cell stage (2). Light chain rearrangement normally takes place only after a successful $\mathrm{IgH}$ rearrangement, which allows the cells to differentiate to the pre$\mathrm{B}$ cell stage (3). In mice, the Igk locus is the primary source for the BCR light chain and will undergo preferential rearrangement. The recombination of the different loci is kept tightly separated, despite the fact that the enzymatic machinery responsible for the processes is essentially the same and is present at both the proand pre- $\mathrm{B}$ cell stages. The light chain loci are maintained in an inaccessible chromatin state via epigenetic mechanisms prior to the pre- $\mathrm{B}$ cell stage, at which point they become available to the rearrangement machinery $(3,4)$. One such epigenetic mark is DNA methylation, a mark that is established at the Igk locus during early embryonic development and which is hereditarily maintained during cell division (5). DNA methylation has been shown to block the activity of the rearrangement machinery in vitro (6). The Igк locus undergoes selective demethylation at the pre-B cell stage, immediately prior to rearrangement $(5,7$, 8). The rearranged Igk allele is unmethylated from that stage onward, while alleles which do not undergo rearrangement remain methylated, even at the mature B cell stage. The low level of methylation is significant for an additional stage of Igk editing during $\mathrm{B}$ cell development, namely for efficient somatic hypermutation (SHM), which will allow affinity maturation of the BCR in activated mature B cells (9). Methylated pre-rearranged Igк sequences do not undergo proper SHM at this stage, whereas identical unmethylated sequences do (10).

The stage-specific transcription, rearrangement, and chromatin structure of the Igк gene is mediated by regulatory sequences within and in proximity to the locus. The locus contains three characterized enhancers, including an intronic enhancer (іЕк) (11), located in the intron between the Jk segments and the Ск exon and two enhancers situated a few 1000 bases downstream of the Ск exon, termed 3'Ек (12) and Ed (13). These enhancers work in cooperation to promote stage-specific chromatin accessibility, DNA demethylation, $\mathrm{V}$ to J rearrangement, heightened transcription of the locus, and SHM in activated B cells, with different enhancers contributing to a varying extent to each one of these processes. іЕк and 3'Ек have been implicated in promoting accessibility and rearrangement of the locus in pre-B cells (14-16), while $3^{\prime} \mathrm{E} \kappa$ and Ed strongly effect the level of transcription and SHM in mature B cells $(17,18)$, neither of which is significantly affected by the deletion of іЕк $(14,18)$. All of the three enhancers contribute together to the demethylation of the locus $(16,19)$. Replacement of iEk with the IgH intronic $\mu$ enhancer is enough to change the rearrangement timing of the locus to the earlier pro-B cell stage, 
showing that it is indeed these sequences which direct the temporal precision of the developmental program (20).

Other than the enhancers, there are a number of additional regulatory elements surrounding the Igא locus, increasing the complexity of the regulation. The recently discovered HS10 element, which lies downstream of Ed, appears to mostly function in plasma cells. While itself being a weak enhancer, HS10 acts as a co-enhancer to strengthen the activities of $3^{\prime} \mathrm{E} \kappa$ and Ed (21). A matrix attachment region (MAR) lies immediately adjacent to $\mathrm{iE \kappa}$ and mediates connections between the locus and the nuclear matrix (22).

The activities of the cis regulatory elements are mediated by various transcription factors, which either activate or repress the enhancer activity. Many of these transcription factors are master regulators of the $\mathrm{B}$ cell lineage, which are important for maintaining B cell identity, such as E2A and PU.1 that bind sites in iEк and $3^{\prime}$ Eк and substantially contribute to the enhancer activity (23-27). However, binding of Pax5, a master regulator of B cell identity, has been surprisingly missing from these enhancers in mature B cells. While binding sites have been identified in $3^{\prime}$ Ек $(24,25,28)$, as well as in K-I and K-II (29, 30), which are regulatory regions (RR) upstream of the JK segments, Pax 5 plays an inhibitory role in this context and is released during the pre-B cell stage when the locus is activated. This is despite the fact that Pax 5 itself is necessary for the active induction of the locus (31).

In this work, we characterize a region adjacent to the MAR/iEk elements. We had previously identified this element as a participant in the demethylation process of the Igк locus in cell culture and thereby designated it Dm (32). Here, we find that this element binds Pax 5 in B cell stages from the pre-B cell stage and onward. It is necessary for demethylation of a pre-rearranged Igк transgene, but deletion of the element in the endogenous locus does not affect the demethylation process. We find that the element contributes to efficient SHM of the Igא locus, indicating that the Dm element functions at more than one stage of B cell development.

\section{MATERIALS AND METHODS \\ MICE}

Targeted mice were backcrossed for 10 generations on a BALB/c background. Igא $\kappa^{\Delta \mathrm{Dm} / \Delta \mathrm{Dm}}$ mice were bred with wild-type (WT) $\mathrm{BALB} / \mathrm{c}$ to produce $\mathrm{Ig}_{\kappa} \mathrm{WT} / \Delta \mathrm{Dm}$ mice. Human $\mathrm{C} \kappa$ knock-in mice (33) (gift from M. Nussenzweig) were bred with either WT BALB/c or $\Delta \mathrm{Dm} B A L B / c$ to produce Ig $^{\mathrm{WT} / \mathrm{WT}} \mathrm{C \kappa}^{\mathrm{h} / \mathrm{m}}$ and

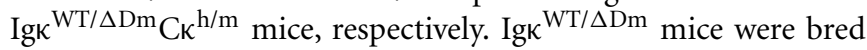
with CAST/EiJ (Cast) mice (Jackson Laboratory) to produce

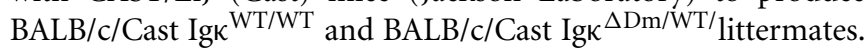
$\mathrm{Rag}^{-/-}$mice (Jackson Laboratories) were bred onto a Cast background. Igא ${ }^{\Delta \mathrm{Dm} / \Delta \mathrm{Dm}}$ were bred onto a C57BL/6 $\mathrm{Rag}^{-/-}$(B6) background containing the $3 \mathrm{H} 9 \mathrm{IgH}$ chain transgene $\left(\mathrm{IgH}^{+}\right)$. CAST/EiJ $\mathrm{Rag1}^{-/-}$mice were bred with $\mathrm{C} 57 \mathrm{BL} / 6 \mathrm{Rag}^{-/-} \mathrm{IgH}^{+}$either with or without a deletion of the Dm element, giving rise to $\mathrm{B} 6 /$ Cast $\mathrm{Rag1}^{-/-} \mathrm{IgH}^{+} \operatorname{Ig\kappa }^{\Delta \mathrm{Dm} / \mathrm{WT}}$ and B6/Cast $\mathrm{Rag}^{-/-} \mathrm{IgH}^{+} \mathrm{Ig \kappa}^{\mathrm{WT} / \mathrm{WT}}$ mice, respectively. Mice were housed in specific pathogen-free conditions at the Hebrew University Medical School animal facility. Transgenic mouse lines $\mathrm{L} \kappa, \mathrm{L} \kappa \Delta \mathrm{Dm}$, and $\mathrm{L} \kappa \Delta 70$ were produced, using the constructs described in the Section "Targeting Constructs," at the Hadassah Hospital Medical School Transgenic Unit.
Two independent founder lines were produced for the Lא trans-

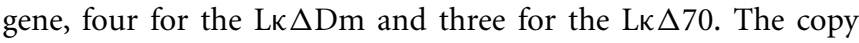
number of the transgene for each founder line varied from low (two insertions) to high (20 insertions) with most lines having a moderate number of insertions (four to eight insertions). All animal procedures were approved by the Animal Care and Use Committee of the Hebrew University of Jerusalem.

\section{TARGETING CONSTRUCTS}

The LK $\Delta \mathrm{Dm}$ construct was prepared using the following steps; the 4.3-kb KpnI-KpnI fragment, containing VкJ5-Ск sequence, was excised from the Lk plasmid (34) and cloned into the KpnI site of the Bluescript vector which was modified to destroy the polylinker XbaI site. The resulting pBSKpn2 plasmid was cut at unique compatible $\mathrm{XbaI}$ and $N$ siI sites, and recirculized, resulting in the deletion of $930 \mathrm{bp} \mathrm{XbaI-NsiI} \mathrm{Dm} \mathrm{fragment} \mathrm{from} \mathrm{the} \mathrm{ЈкС \kappa}$ intron. The KpnI-KpnI Dm-deleted fragment was excised and

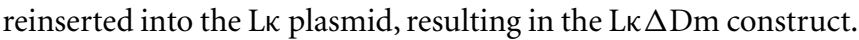

The Lк $\Delta 70$ construct was prepared using the following steps; the HindIII-blunt TaqI 2.6-kb fragment, containing the germline $\mathrm{J} \kappa$ region, was cloned to HindIII-EcoRV sites of the Bluescript vector. Next, a blunted BstEII-BglII 2-kb fragment containing the Ск exon was cloned into blunted EcoRI-BamHI sites of the previously described $\mathrm{J} \kappa$ containing Bluescript vector to yield the $\mathrm{p}-\Delta 70$ construct, which had the $70 \mathrm{bp}$ TaqI-BstEII deletion introduced into the HindIII/BglII 5.6-kb JкCк germline sequence. The 1-kb intact intronic XbaI-HindIII region of pBSKpn2 plasmid (previously described, containing the $K p n I-K p n I$ fragment from the Lא plasmid) was replaced with $X b a I-H i n d I I I$ fragment bearing the 70 bp deletion, excised from p- $\Delta 70$. The 4.2-kb KpnI-KpnI fragment with the $70 \mathrm{bp}$ deletion was excised from the resulting pBSKpn $2 \Delta 70$ plasmid and cloned back into the Lк plasmid, replacing the original $4.3-\mathrm{kb} K p n \mathrm{I}-K p n \mathrm{I}$ sequence, and yielding

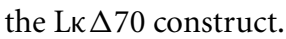

The $\Delta \mathrm{Dm}$ targeting vector was prepared as using the following steps; a short arm of homology (neo-SAH) plasmid was constructed by using BanII (ends filled with Klenow) and NsiI to excise the 1.25-kb MAR and Eik containing fragment from the pBкMAR plasmid. This fragment was cloned into the sticky XbaI and blunted PstI sites of the Bluescript vector. This construct was next cut at the polylinker sites ClaI and EcoRI and used for insertion of the 1.26-kb Not I-XbaI loxP flanked neoR gene fragment from the pMMneoflox- 8 plasmid (all restriction ends were made blunt by reaction with the Klenow fragment), a long arm of homology (TK-LAH) plasmid was constructed by excision of the 7.1-kb Pst I-Pst I germline J $\mathrm{\kappa}-\mathrm{C} \kappa$ region containing fragment from pSPIg8 plasmid (ends were blunted by reaction with T4 polymerase) and ligation into the HindIII site (blunted with reaction with Klenow fragment) of pIC19R/MC1-TK. The final $\Delta \mathrm{Dm}$ targeting vector was produced by cloning of the $8.9-\mathrm{kb}$ XhoI-SalI fragment from TK-LAH into the neo-SAH SalI polylinker site. Targeting strategy is illustrated in Figure S1 in Supplementary Material.

\section{CELLS AND CULTURES}

All cells in this manuscript were grown in RPMI 1640 medium (Gibco) supplemented with 10\% fetal calf serum, $2 \mathrm{mM}$ 
L-Glutamine, $100 \mu \mathrm{g} / \mathrm{ml}$ penicillin, $100 \mu \mathrm{g} / \mathrm{ml}$ streptomycin, and $50 \mu \mathrm{M}$ 2-mercaptoethanol. BaF3 cell medium was additionally supplemented with IL3 secreted by WEHI-3b cells. IL-7dependent pre-B cell cultures used for chromatin immunoprecipitation (ChIP) analysis were performed as has been previously described (35). COP8 cells were transiently transfected with a Pax5 expression plasmid (gift from M. Busslinger) using the DEAE dextran method (36).

\section{ISOLATION AND ANALYSIS OF LYMPHOID CELLS FROM BONE MARROW AND SPLEEN}

Bone marrow cells from femur and tibia bones were flushed out with PBS using a $25 \mathrm{G}$ syringe needle. Spleens were disrupted and pulp dispersed in PBS. Erythrocytes were lysed with RBC lysis solution (Biological industries) and cells were washed. When indicated, cells were isolated on magnetic MACS columns (Miltenyi Biotech) by positive selection with either $\alpha$ CD19 magnetic beads or streptavidin magnetic beads and biotinylated $\alpha$ B220 (Miltenyi Biotech), according to the manufacturer's instructions. Cell purity following isolation was assayed as $<95 \%$ by flow cytometry (LSR II, BD Bioscience).

Cells from erythrocyte disrupted spleens and bone marrows were stained with the antibodies indicated and cellular composition was analyzed by flow cytometry (LSR II, BD Bioscience). The antibodies used in this report include anti-mouseIgк-PE (Southern Biotech), anti-human-Igk-FITC (Southern Biotech), anti-IgM-APC (eBioscience), anti-B220-PerCP-Cy5.5 (Biolegend), anti-CD43-PE (Biolegend), anti-IgD-FITC (eBioscience). Flow cytometry output was analyzed using Flowing Software v2.5.0 (Turku Centre for Biotechnology).

\section{ANALYSIS OF DNA METHYLATION BY SOUTHERN HYBRIDIZATION}

Cellular genomic DNA $(5-15 \mu \mathrm{g})$ was digested with the specified enzymes, electrophoresed in native (Tris-acetate) agarose gels, denatured and transferred to nitrocellulose. DNA was then hybridized with the specific radioactive probes and analyzed by autoradiography (37). Hybridization was carried out at $65^{\circ} \mathrm{C}$ for $16 \mathrm{~h}$. The degree of methylation was measured semiquantitatively using a PhosphorImager BAS-1800 (Fuji) and Tina2.10 g software (IsotopenMedgerate $\mathrm{GmbH}$ ).

\section{NUCLEAR EXTRACT PREPARATION}

Cells $\left(3-5 \times 10^{6}\right)$ were washed in PBS, resuspended in low salt buffer (10 mM HEPES pH 7.9, $10 \mathrm{mM} \mathrm{KCl,} 0.1 \mathrm{mM}$ EDTA, $0.1 \mathrm{mM}$ EGTA, $1 \mathrm{mM}$ DTT, $0.5 \mathrm{mM}$ PMSF, $20 \mu \mathrm{g} / \mathrm{ml}$ aprotinin, $10 \mu \mathrm{g} / \mathrm{ml}$ leupeptin) and incubated for $10 \mathrm{~min}$ on ice. NP-40 was then added to a final concentration of $0.66 \%$, the mixture was vortexed briefly and centrifuged for $30 \mathrm{~s}, 16,000 \mathrm{~g}$. Nuclei were resuspended in high salt buffer (20 mM HEPES pH 7.9, $0.4 \mathrm{mM} \mathrm{KCl}$, $1 \mathrm{mM}$ EDTA, $1 \mathrm{mM}$ EGTA, $1 \mathrm{mM}$ DTT, $1 \mathrm{mM}$ PMSF, $20 \mu \mathrm{g} / \mathrm{ml}$ aprotinin, $10 \mu \mathrm{g} / \mathrm{ml}$ leupeptin) and rotated for $20 \mathrm{~min}$ at $4^{\circ} \mathrm{C}$. Nuclear debris was removed by centrifugation at $16,000 \mathrm{~g}$ for $20 \mathrm{~min}$ at $4^{\circ} \mathrm{C}$.

\section{ELECTROPHORETIC MOBILITY SHIFT ASSAY}

Oligonucleotide probes were end-labeled with $\alpha^{32} \mathrm{P}$-dCTP using Klenow fragment. Two micrograms of nuclear extract was incubated with $0.3 \mathrm{ng}$ of the radioactive double strand probe in a solution containing $2 \mu \mathrm{g}$ poly-dI-dC, $10 \mathrm{mM}$ Tris- $\mathrm{HCl} \mathrm{pH}$ 7.9, $10 \%$ glycerol, $100 \mathrm{mM} \mathrm{KCl}$, and $4 \mathrm{mM} \mathrm{DTT}$ for $20 \mathrm{~min}$ at $25^{\circ} \mathrm{C}$. In competition assay, 100 -fold molar excess of an unlabeled probe was preincubated for $10 \mathrm{~min}$ prior to the addition of the radiolabeled probe. In supershift assays, the indicated antisera (antibodies A1 and A2 kindly provided by Meinrad Busslinger) were added to the nuclear extract $15 \mathrm{~min}$ prior to the addition of the probe. Samples were then electrophoresed at room temperature on a $4 \%$ polyacrylamide gel (19:1 acrylamide/bis) in $0.25 \times$ TBE buffer. Gels were dried and bands were visualized by autoradiography. Probes used for assays were Dm-70 bp 5'-CGATTGTAATTTTATATCGCCAGCAATGGACTGAAACGGT CCGCAACCTCTTCTTTACAACTGGGTGAC-3' and the Pax5binding site from the promoter of sea urchin $\mathrm{H} 2 \mathrm{a}-2.25^{\prime}$-GGG TTGTGACGCAGCGGTGGGTGACGACTCCAGAGTCGACA-3'.

\section{DNAse I FOOTPRINTING}

TaqI-SacII fragment (130 bp) from the Dm segment, encompassing the detected Pax5-binding site, was labeled with ${ }^{32} \mathrm{P}$-dCTP at TaqI end by a fill-in reaction with Klenow fragment to a specific activity greater than $10^{4} \mathrm{cpm} / \mathrm{ng}$ of DNA. Probes were incubated for $20 \mathrm{~min}$ at room temperature with $20 \mu \mathrm{g}$ of nuclear extract in a $50-\mu \mathrm{l}$ reaction mixture containing $10 \mathrm{mM}$ Tris $\mathrm{pH} 7.8$, $14 \%$ glycerol, $57 \mathrm{mM} \mathrm{KCl}, 4 \mathrm{mM}$ DTT, and $0.2 \mu \mathrm{g}$ poly (dI-dC). DNase I (0.5-1 U; Promega) diluted in $50 \mathrm{mM} \mathrm{MgCl}_{2}, 10 \mathrm{mM}$ $\mathrm{CaCl}_{2}$ was added for $1 \mathrm{~min}$. The reaction was terminated by addition of $150 \mu \mathrm{l}$ of a stop solution containing $200 \mathrm{mM} \mathrm{NaCl}$, $20 \mathrm{mM}$ EDTA, $1 \% \mathrm{SDS}$, and $5 \mu \mathrm{g}$ yeast tRNA. DNA was extracted with phenol-chloroform, ethanol precipitated, dissolved in loading buffer (deionized Formamide - $5 \mathrm{mM}$ EDTA), denatured for $10 \mathrm{~min}$ at $85^{\circ} \mathrm{C}$ and separated on a $6 \%$ polyacrylamide sequencing gel containing $7 \mathrm{M}$ urea. Sequencing reactions performed using the Maxam and Gilbert procedure were run parallel to each probe.

\section{BISULFITE SEQUENCING}

DNA was converted by bisulfite treatment using the EpiTect Bisulfite kit (Qiagen) and amplified by PCR with GoTaq (Promega) using the following primers; BisDm F 5'-TTGATAGATAGTTTAA GGGGTTTTT-3', BisDm R 5'-ATCTATCACATCTCTATTCTCTT CAAATTA- $3^{\prime}$, BisJ $\kappa 2$ F 5' -TTTTTGGAGAATGAATGTTAGTGTA ATAAT-3', BisJк2 R 5'-TAAAACAATTTTCCCTCCTTAACAC-3'; ionJ $22 \mathrm{~F} 5^{\prime}$-(ion torrent A adapter)-(index)-GAAATGTTTAAAGA AGTAGGGTAGTTTGT-3'; ionJK2 R 5'-(ion torrent P1 adapter)-

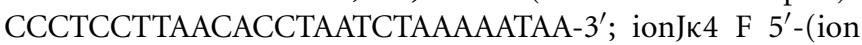
torrent A adapter)-(index)-ACCAAAAATAACTCATTTAACCAA AATAT- $3^{\prime}$, ion J $\kappa 4 \mathrm{R} 5^{\prime}$-(ion torrent $\mathrm{P} 1$ adapter)-TGATTTTATGTT AGATTTGTGGGAR-3' ${ }^{\prime}$. Amplicons were visualized on a $1.5 \%$ agarose gel, excised, and purified with the Qiaquick gel extraction kit (Qiagen). Amplicons intended for standard Sanger sequencing were TA cloned using pGEM-T easy kit (Promega). PCR with universal T7 and SP6 primers was performed on transformed colonies and correctly inserted clonal amplicons were sequenced by Sanger sequencing (ABI-Prism-3700). Samples amplified with ion torrent fusion primers were sequenced on an Ion Torrent Personal Genome machine (Invitrogen). 


\section{CHROMATIN IMMUNOPRECIPITATION}

IL-7-dependent pre-B cell cultures were made from the bone marrow of Igא $\mathrm{WT}^{\mathrm{W}} \Delta \mathrm{Dm}$ mice as has been previously described (35). Cells were crosslinked with formaldehyde, chromatin extracted, and immunoprecipitated with an antibody directed against Pax5 (5 $\mu \mathrm{g}$ per $30 \mu \mathrm{g}$ DNA) (SantaCruz). Semi-quantitative PCR was carried out on input DNA compared to immunoprecipitated DNA using primers specific for the Dm element and primers spanning the Dm deletion in order to test the enrichment on the WT and $\triangle \mathrm{Dm}$ alleles separately. PCR amplicons were visualized on an $8 \%$ polyacrylamide gel. Primers used: $\Delta$ DmChIP-F 5'-CCAAGAGATTGGATCGGAGA-3', $5^{\prime}$ DmChIPR 5'-CCATGACTTTTGCTGGCTGT-3'; WTDmChIP-F 5'-GGCC ACGGTTTTGTAAGACA-3', WTDmChIP-R $5^{\prime}$-CAGGGTGAA CGCCAAATG-3', CD19-F 5'-GATTTGGAAGAGTGCCTACA-3', CD19-R $5^{\prime}$-GCCTGCCTCCTACTAAGGTA- $3^{\prime}, \beta$-actin-F $5^{\prime}$-CG CCATGGATGACGATATCG- $3^{\prime}, \beta$-actin-R $5^{\prime}$-CGAAGCCGGCTT TGCACATG-3'.

\section{SOMATIC HYPERMUTATION ANALYSIS OF PEYER'S PATCHES B CELLS}

Peyer's patches (PP) were dissected from the small intestines of

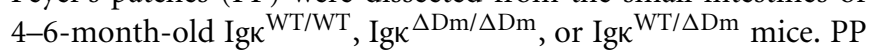
from three to four mice were pooled for each experiment. PP were mashed through a $70 \mu \mathrm{m}$ nylon mesh and washed with PBS to produce single cell suspensions. Cells were washed with PBS-0.5\% BSA and labeled with PNA-FITC (Vector Labs) and $\alpha$ B220-PE (BD Bioscience). Germinal center $\mathrm{B} 220^{+} / \mathrm{PNA}^{\text {high }} \mathrm{B}$ cells were sorted (FACSStar BD) to greater than $90 \%$ purity. WT and $\triangle \mathrm{Dm}$

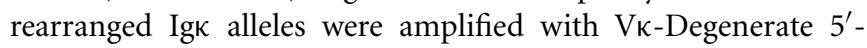
GTCCCTGCCAGGTTYAGTGGCAGTGGRTCWRGGAC- $3^{\prime}$ and R3-1 5'-CAGACCCTGGTCTAATGGTTTGTAACCACATGGG-3' primers using high fidelity PCR kit (Roche) with an initial denaturation of $4 \mathrm{~min}$ at $94^{\circ} \mathrm{C}$, followed by 35 cycles of denaturation at $94^{\circ} \mathrm{C}$ for $15 \mathrm{~s}$ and annealing combined with elongation at $68^{\circ} \mathrm{C}$ for 2 min. $3^{\prime} \mathrm{A}$-overhang nucleotides were added by $20 \mathrm{~min}$ incubation with Taq polymerase and ATP at $72^{\circ} \mathrm{C}$. PCR fragments corresponding to $\mathrm{V} \kappa-\mathrm{J} \kappa 5$ rearrangement of the WT and $\triangle \mathrm{DM}$ ( 2.2 and $1.3 \mathrm{~kb}$, respectively) were visualized on a $0.8 \%$ agarose gel, excised and purified with the QIAquick gel extraction kit and cloned into the TOPO-2.1 TA cloning vector (Invitrogen). Plasmids from single colonies were prepared and sequenced by Sanger sequencing (ABI-Prism-3700). Sequences were aligned to the Igк locus and mutations in the $188 \mathrm{bp}$ region downstream of

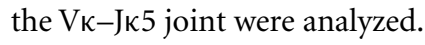

\section{PYROSEQUENCING}

RNA was extracted using tri-reagent (Sigma-Aldrich) from $\mathrm{CD}^{+}{ }^{+}$MACS sorted (Miltenyi Biotec) splenic cells of

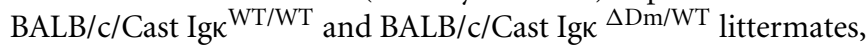
as well as control $\mathrm{BALB} / \mathrm{c}$ and Cast mice. $\mathrm{cDNA}$ was prepared with mMLV reverse transcriptase (Promega) using random hexamer primers (Thermo Scientific). Rearranged Igк transcripts were amplified with Vк-degenerate: 5'-GTCCCTGCCAGGTTYAGT

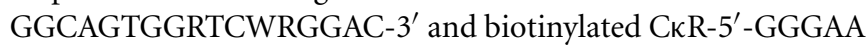
GCCTCCAAGACCTTA-3'. Resulting amplicons were visualized on a $1.5 \%$ agarose gel, excised and purified with the QIAquick gel extraction kit (Qiagen). Allelic distribution of
BALB/c/Cast transcripts was assessed by pyrosequencing on a PyroMark Q24 instrument (Qiagen) using Ск-pyro primer 5'-ACATCAACTTCACCCAT-3'.

\section{LUCIFERASE REPORTER ASSAY}

M12 cells were transiently transfected using the DEAE dextran method (36) with a luciferase reporter plasmid containing the minimal $\beta$-globin promoter TATA box (pTATA), without any additional regulatory elements or with insertions of the Dm element, $\mathrm{iE \kappa}$, or four NF-кB binding sites immediately upstream of the promoter. The cells were co-transfected with $\mathrm{p} \beta$-GAL to normalize for transfection efficiency. Luciferase activity was measured using the Luciferase Assay System (Promega) according to the manufacturer's instructions.

\section{RESULTS}

\section{CHARACTERIZATION OF THE Dm ELEMENT}

We have previously identified an element lying 700 bp upstream of the iEк which facilitates demethylation of the Igк locus in cell culture, in cooperation with iEк (32). The element, designated $\mathrm{Dm}$, is not part of the previously defined core iЕк (Figure 1A). The Dm element, as determined by our previous experiments, spans $\sim 1 \mathrm{~kb}$ and contains numerous areas which are conserved throughout different species (Figure 1A). The element itself contains a stretch of $\sim 200$ bp with the highest density of CpG sites found within the Igk locus. In order to see whether this element was transcriptionally active, we tested its functionality in an enhancer reporter assay. We compared its activity in a reporter plasmid to the well-characterized iЕк (Figure 1B). Luciferase assays show that the Dm element acts only as a weak transcriptional enhancer which is about sevenfold weaker than the core intronic enhancer in M12 B cell lymphoma cells (Figure 1C), suggesting that the Dm element on its own does not exert its effect by direct transcriptional activation.

\section{Pax5 BINDING AT THE Dm ELEMENT}

Cis regulatory elements, such as enhancers and promoters, convey their influence on cellular phenotypes by binding trans regulatory transcription factors, which mediate transcription and changes in chromatin structure. As the Igא locus is selectively active in B cells, starting from the pre-B cell stage, we speculated that the Dm element may bind B cell-specific transcription factors, thus mediating the changes it induces. Upon searching for potential binding sites for key B cell transcription regulators, we identified an area within the CpG-rich segment with remarkable similarity to the Pax 5 consensus sequence (38) (Figure 2A). A 70-bp probe containing this sequence is shifted to a specific height when incubated with nuclear extracts from $B$ lineage cells which have passed the pro- $B$ cell stage, but not in other cell types tested in an electro-mobility shift assay (EMSA) (Figure 2B). These results clearly show that the binding of this protein is specific for the stages when the Igא locus is active. Notably, this specific shift can be attained using a fibroblast extract, which normally does not produce such a shift, by forced expression of Pax5 (Figure 2C), and titrated away by competition with a probe containing the Pax5-binding site of the $\mathrm{H} 2 \mathrm{a}-2.2$ promoter, strongly implying that indeed the Pax 5 protein is binding at this site. When the nuclear extract is incubated 


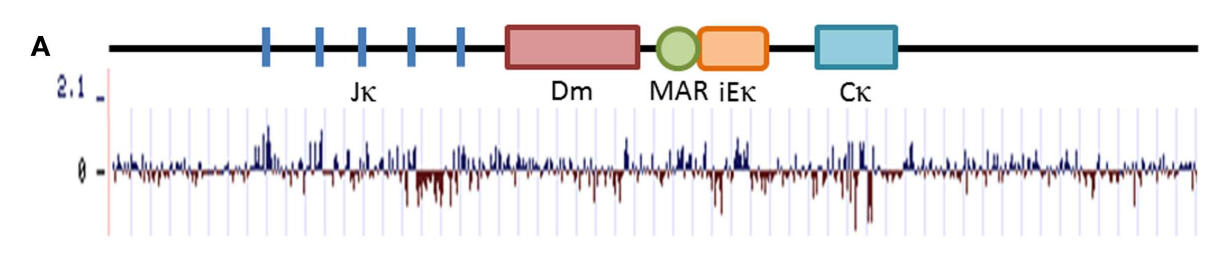

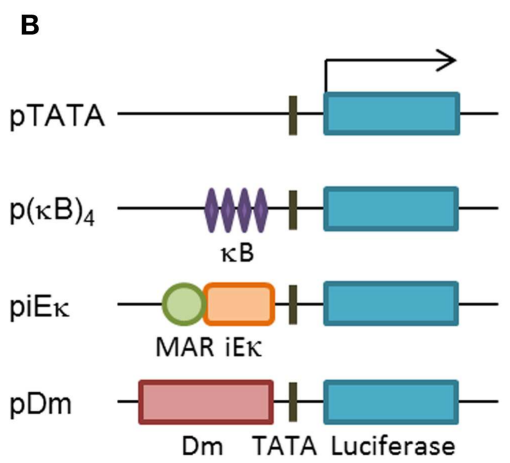

FIGURE 1 | Conservation and transcriptional activity of the Dm element. (A) Schematic map of the lgк locus, drawn to scale. Basewise conservation across mammalian genomes is shown graphically, adapted from UCSC genome browser "Conservation" track. (B) Schematic map of transfected plasmid constructs. (C) Average relative luciferase activity in M12 cells

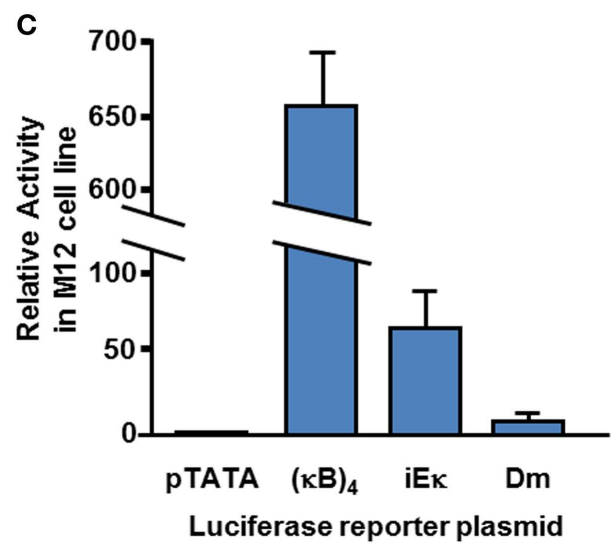

transfected with the indicated plasmids. Plasmids were co-transfected with a constitutive $\beta$-Gal-expressing plasmid and luciferase activity was normalized for transfection efficiency to $\beta$-Gal activity. Transfection and luciferase assay was carried out at least three times for each construct. Error bars represent the standard deviation of the luciferase activity. with an antibody raised against the DNA-binding domain of Pax5 (designated A1), the shift on the EMSA gel disappears, whereas incubation with an antibody recognizing the Pax5 transactivation domain (designated A2) introduces a supershift, confirming that the 70-bp probe indeed specifically binds the Pax5 transcription factor (Figure 2D). DNase I footprinting using nuclei of the Pax5-expressing M12 B cell lymphoma cell line shows a definitive protection at the putative Pax5-binding site in comparison to S194 plasmacytoma cells which do not express Pax5 (Figure 2E). Interestingly, this specific footprint correlates precisely with the predicted Pax5-binding site. ChIP was performed on pre-B cells from Igk ${ }^{\mathrm{WT}} / \Delta \mathrm{Dm}$ mice (introduction of the $\Delta \mathrm{Dm}$ allele into mice is described in Section Characterization of Methylation, Rearrangement and B Cell Development in Dm Knockout Mice) with an antibody recognizing the Pax5 protein. While the Dm positive allele showed significant enrichment for Pax5, the deleted allele was not enriched for Pax5-binding (Figure 2F). These results indicate that Pax5 indeed binds in this region in vivo and that the binding is directly dependent on the presence of the Dm element. Altogether, the above described data shows that Pax 5 specifically binds to the Dm element in vivo.

\section{Dm FACILITATES DNA DEMETHYLATION OF Igk TRANSGENES}

We wished to further investigate the role of the Dm element in demethylation of the Igк locus. In order to do so, we introduced a well-characterized transgene $(34,39)$ containing a pre-rearranged Igk allele to mice, termed Lк (Figure 3A). Two additional transgenic mice were produced with modified constructs, one containing a deletion of the entire Dm locus, termed L $\Delta \mathrm{Dm}$, and the second containing a deletion of the $70 \mathrm{bp}$ region containing the Pax5-binding site, termed L $\Delta 70$ (Figure 3A). DNA from splenic $\mathrm{B}^{2} 20^{+}$cells was assayed for the methylation of these transgenes by restriction analysis, which allows for simple differentiation between the transgenic and endogenous regions. Digestion with

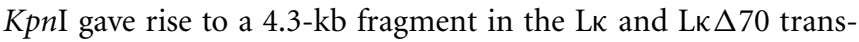
genes and a 3.4-kb fragment in the L $\alpha \Delta \mathrm{Dm}$ transgene, whereas the endogenous locus yields a $15-\mathrm{kb}$ fragment. These fragments were further digested with methylation-sensitive restriction enzymes AciI and HhaI (HhaI was not used to assess the $\mathrm{L} \kappa \Delta \mathrm{Dm}$ state since the HhaI site is deleted in this transgene). The digested DNA was hybridized with a probe recognizing the MAR and iЕk sequences. To assess the level of methylation, the amount of the undigested DNA was measured using a PhosphorImager. Interestingly, while the Lא transgene was almost completely unmethylated, with only $8 \%$ of the DNA remaining undigested (Figures $3 \mathrm{~B}, \mathrm{C}$ ), the L $\Delta \Delta \mathrm{Dm}$ transgene was highly methylated (73\%) (Figures 3B,D), indicating that indeed the Dm element facilitates the hypomethylation of the Igk locus in B cells. Notably, deletion of only $70 \mathrm{bp}$ from the Dm in the Lк $\Delta 70$ transgene reduced the ability of the transgene to become unmethylated (50\%) (Figures 3C,D).

Bisulfite analysis of the CpG-rich region surrounding the Pax5-

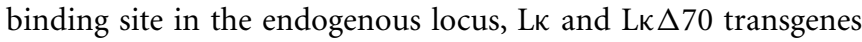
showed a picture that agrees quite nicely with the above results (the $\mathrm{L} \kappa \Delta \mathrm{Dm}$ was not assayed in this manner, since this region is deleted within the transgene). These results take into consideration the difference between the methylation levels measured by bisulfite sequencing, which probes all $\mathrm{CpG}$ sites in the region, and the restriction analysis which measures the methylation only at 

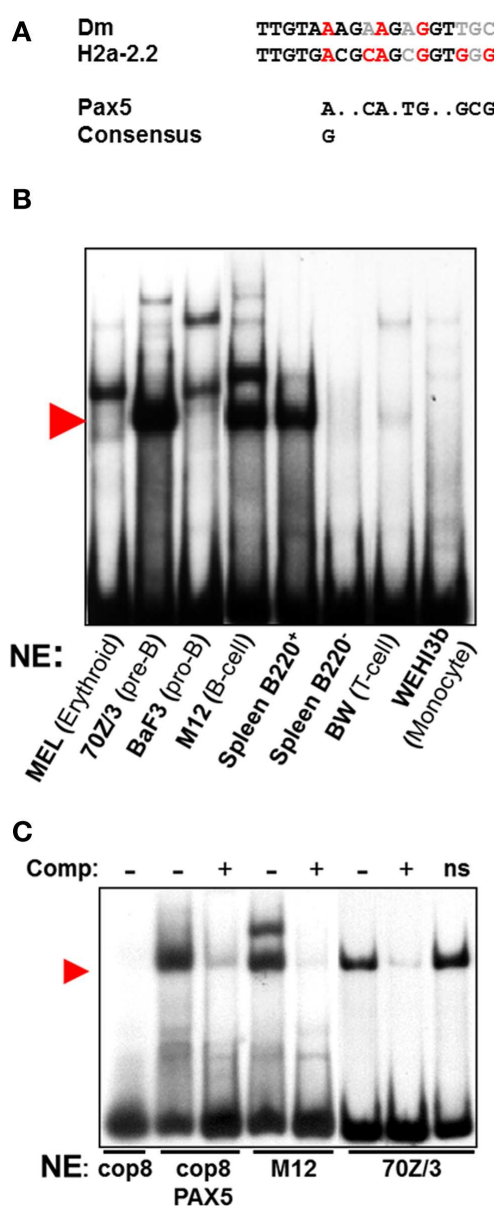

FIGURE 2 | Pax5-binding within the Dm element. (A) Comparison of the putative Pax5-binding site within the Dm element, known Pax5-binding site in sea urchin $\mathrm{H} 2 \mathrm{a}-2.2$ promoter and Pax 5 consensus sequence. Bases which match the consensus sequence are marked in red, while bases which do not match are marked in gray. (B) Electro-mobility shift assay (EMSA) of Taql-BstEll 70 bp fragment from the Dm element, containing the putative Pax5-binding site, with the indicated hematopoietic cell type nuclear extracts. Red arrowhead indicates B cell lineage-specific shift.

(C) Competition EMSA. Unlabeled $\mathrm{H} 2 \mathrm{a}-2.2$ probe competes with radioactive Taql-BstEII Dm probe and reduces shift in B lineage cell extracts (M12, $70 Z / 3$ ), and in extracts of fibroblast cells (cop8) transfected with a Pax5 expression vector. Nonsense unlabeled probe (ns) is unable to compete with Dm probe. Red arrowhead indicates specific shift. (D) Supershift assay with Taql-BstEII Dm probe, which was incubated with antibodies (ab) raised against the DNA-binding site of Pax5 (A1), the transactivation domain (A2),
NE:

$$
\text { CGTTTCAGTC }
$$$$
\text { GGAACCA }
$$$$
\text { GG }
$$

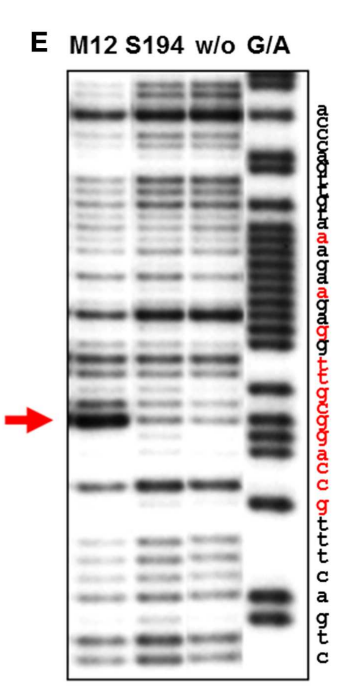

$\mathbf{F}$

$$
\text { Input } \alpha \mathrm{Pax} 5 \quad \text { Input IgG }
$$
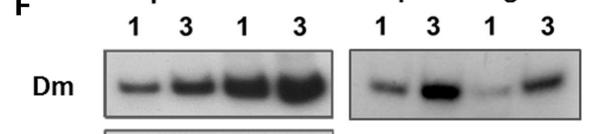

$\Delta \mathrm{Dm}$

CD19
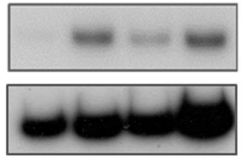

$\beta$-actin

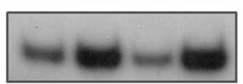

or general rabbit antisera (P.I.). (E) DNase I footprinting assay on end-labeled TaqI-Sacll probe from the Dm element. Labeled probe was incubated with nuclear extracts from the indicated cell types. A control Maxam and Gilbert reaction (G/A) was run in parallel. Footprint specific to Pax5-expressing M12 cells is indicated with a red arrow. Location of the putative Pax5-binding site is marked in red on the nucleotide sequence. (F) Chromatin immunoprecipitation (ChIP) enrichment of Pax5 at the Dm element in $\lg \kappa^{\mathrm{w} t / \Delta \mathrm{Dm}}$ cultured pre-B cells. Enrichment was measured by

semi-quantitative PCR via comparison of the input DNA (Input) to the immunoprecipitated fraction ( $\alpha$ Pax5), using primers specific to the $\mathrm{Dm}$ element $(D m)$ and the deleted allele $(\Delta \mathrm{Dm})$. One and three times the amount of PCR template were run in parallel to ensure linearity. Positive (CD19 promoter) and negative ( $\beta$-actin promoter) controls for Pax5-binding were analyzed in parallel to ensure specificity of the enrichment. ChIP with a non-specific antibody (lgG) does not enrich the Dm element. the sites which correspond to the digestion site. The endogenous locus is close to $50 \%$ methylated, as expected from a region which undergoes monoallelic demethylation (Figure 3E). The Lк $\Delta 70$ transgene is $76 \%$ methylated, while the Lא transgene is completely unmethylated (Figure 3E). In order to see how these results correlate with the restriction analysis, the percent of sequences which would be protected from AciI digestion was assessed. Fifty-seven percent of the L $\Delta 70$ sequences remain protected, supporting the restriction analysis results. These experiments clearly show that the Dm element contributes to the demethylation of the Igк locus in vivo, results that support previously published data obtained from cell culture systems.

\section{CHARACTERIZATION OF METHYLATION, REARRANGEMENT, AND B CELL DEVELOPMENT IN Dm KNOCKOUT MICE}

Given the results in transgenic mice, we generated a knockout mouse in which the entire Dm element in the endogenous locus was replaced with a LoxP-flanked Neo gene which was then excised from the genome (Figure 4A; Figure S1 in Supplementary Material). We assessed the methylation pattern of the Igк locus by 

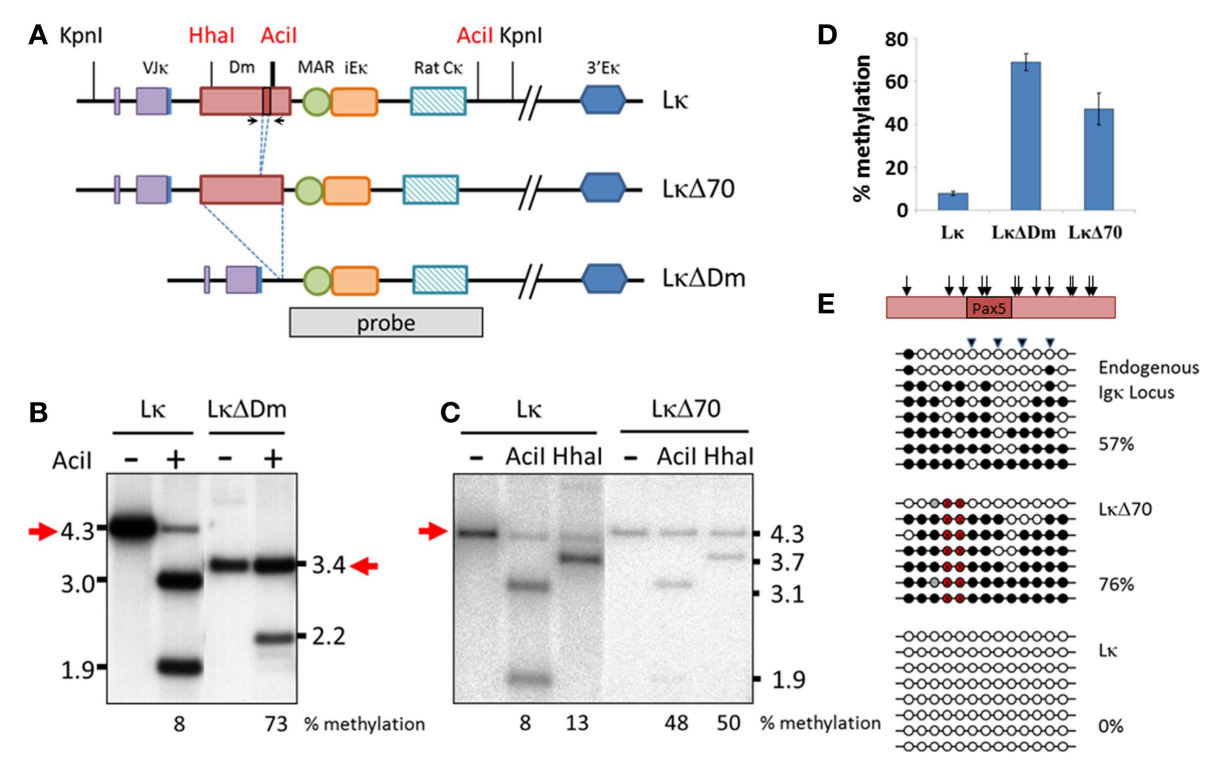

FIGURE 3 | Effect of Dm element on methylation of lgk locus in transgenic mice. (A) Schematic map of the transgenes and probe used in experiments. Bold Acil line indicates multiple Acil restriction sites within close proximity. $(\mathbf{B}, \mathbf{C})$ Southern blot assay assessing methylation state of $L \kappa, L \kappa \Delta D m$ (B) and $L \kappa \Delta 70$ (C) transgenes in $B 220^{+}$splenic $B$ cells. DNA was digested with Kpnl either alone or with methylation sensitive enzymes Acil or Hhal and hybridized with the indicated probe. Methylation levels were quantified by phosphorlmager. (D) Graphical representation of the average methylation levels at Acil sites of the indicated transgenes, as quantified by phosphorlmager. Methylation was measured in DNA from two to four independent founder mice for each transgene. Error bars represent standard deviation of the methylation levels. (E) Bisulfite analysis of $\mathrm{CpGs}$ flanking the Pax5-binding sequence of the Dm element. Triangles mark $\mathrm{CpGs}$ recognized by Acil restriction enzyme. Black circles signify methylated, white signify unmethylated, gray signify undetermined, and red signify $\mathrm{CpGs}$ deleted in transgene. Percentage of methylated $\mathrm{CpGs}$ is noted. Relative location of the CpGs within the Dm element is indicated with arrows on schematic representation of the genomic region. Location of primers is marked by arrows in (A). bisulfite analysis of the J $\kappa 2$ fragment in ex vivo mature B cells. Surprisingly, given the strong phenotype in transgenic mice, no significant difference was seen between the methylation levels of

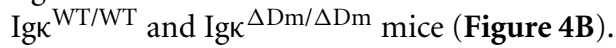

We then proceeded to investigate whether the methylation patterns at the Igк locus are affected by deletion of the Dm element in the pre-B cell stage, which is the very first stage in which demethylation of the locus is detected. To this end, Igא ${ }^{\Delta \mathrm{Dm}}$ mice were bred onto a Rag $1^{-/-}$background, effectively blocking rearrangement of the Igк locus and differentiation to the mature B cell stage. Expression of a pre-rearranged $\mathrm{IgH}$ transgene was ensured in order to allow the cells to express the pre-BCR and differentiate to the pre-B cell stage. These mice were further bred with $\operatorname{Rag} 1^{-1-} M$. castaneous mice, which contain an intact Dm element, thus allowing distinction between the WT and the Dm-deleted alleles based on the strain-specific DNA polymorphisms. Ex vivo $\mathrm{CD} 19^{+}$bone marrow cells were purified from B6/Cast $\mathrm{Rag}^{-/-} \mathrm{IgH}^{+} \mathrm{Ig \kappa}^{\Delta \mathrm{Dm} / \mathrm{WT}}$ and B6/Cast $\mathrm{Rag1}^{-/-} \mathrm{IgH}^{+} \mathrm{Ig \kappa}^{\mathrm{WT} / \mathrm{WT}}$ mice and the methylation of the J $\kappa 2$ and $\mathrm{J} \kappa 4$ segments was determined by high-throughput sequencing. We did not, however, detect significant differences in levels of methylation between the WT and $\Delta \mathrm{Dm}$ alleles (Figure 4C, Figure S2 in Supplementary Material). Taken together, we find that, while the Dm element plays a role in demethylation of the Igк locus in transgenes, this role is not translated to the endogenous locus, probably due to redundancy of the many enhancers of the locus, not all of which are present in the transgene.
We explored the possibility that the Dm element may affect other developmental processes pertaining the Igк locus and normal B cell development, as has been observed for cis regulatory elements in the locus such as the enhancers. There was no significant difference seen in the levels of rearrangement of the WT versus $\triangle \mathrm{Dm}$ allele, as assessed by FACS and pyrosequencing analyses (Figure S3 in Supplementary Material). The pyrosequencing results also indicate that the level of Igא transcription is not changed by the deletion of the Dm element, supporting the above described results showing that the Dm element is a weak transcriptional enhancer. The B cell development in the bone marrow of Igк ${ }^{\Delta \mathrm{Dm} / \Delta \mathrm{Dm}}$ mice appeared normal, with proportions of pro-, pre-, immature, and mature B cells similar to those of WT mice (Figure 4D, Figure S4 in Supplementary Material). Overall, these results indicate that, in the endogenous locus, deletion of the Dm element does not curtail these early stages of B cell development.

\section{EFFECT OF Dm ELEMENT ON SHM}

We investigated whether deletion of the Dm element affects a later stage of Igא maturation, specifically the process of SHM in activated B cells. Levels of SHM in Igא ${ }^{\mathrm{WT} / \mathrm{WT}}$ mice versus Igא ${ }^{\Delta \mathrm{Dm} / \Delta \mathrm{Dm}}$ mice were examined, and a significant drop in amount of mutations in the germinal center B220 ${ }^{+} \mathrm{PNA}^{\text {high }} \mathrm{B}$ cells from Peyer's patches of the Dm negative mice was observed (Figures 5A,B). In order to rule out mouse to mouse variation, which could potentially give rise to such an effect, $\mathrm{SHM}$ in heterozygous Igא $\mathrm{WT} / \Delta \mathrm{Dm}$ 

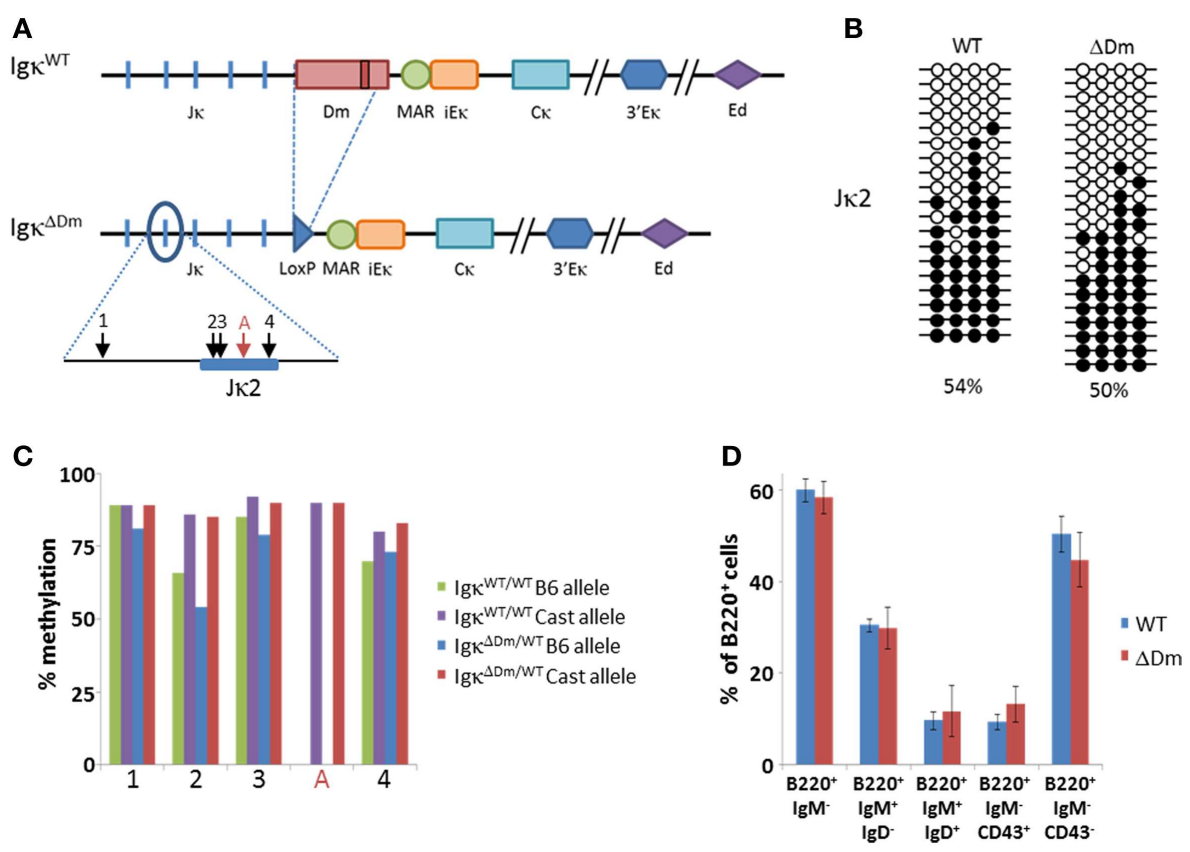

FIGURE 4 | Effect of deletion of the Dm element at the endogenous locus on Igк methylation and B cell development in the bone marrow.

(A) Schematic map of the endogenous Igк locus in wild-type (WT) and Dm knockout $(\Delta \mathrm{Dm})$ mice. Relative locations of $\mathrm{CpGs}$ in $\mathrm{J}_{\kappa} 2$ region are indicated with arrows. CpG present only in Castaneous (Cast) strain is marked with a red arrow. (B) Bisulfite analysis of $\mathrm{CpGs}$ at the $\mathrm{J}_{\kappa} 2$ region in splenic $\mathrm{CD} 19^{+} \mathrm{B}$ cells from WT and $\Delta \mathrm{Dm}$ mice. Black circles signify methylated $\mathrm{CpGs}$, white circles signify unmethylated $\mathrm{CpGs}$. Percentage of methylated $\mathrm{CpG}$ s is noted. (C) Bisulfite analysis by high-throughput sequencing of $\mathrm{J}_{\kappa} 2$ region from
$\mathrm{CD}_{19}{ }^{+}$bone marrow pre-B cells from Rag1 ${ }^{-1-} \mathrm{C} 57 \mathrm{BL} / 6 /$ Castaneous $\mathrm{IgH}-3 \mathrm{H} 9-\mathrm{Tg}$ mice with or without a deletion of the Dm element on the C57BL/6 (B6) allele. Copies (1600-3000) of each CpG from each genotype were analyzed. Alleles were differentiated by strain-specific polymorphic sites within the amplified regions. The methylation state of each $\mathrm{CpG}$ is summarized graphically. (D) Summary of proportions of B cell populations within bone marrows of WT and $\triangle \mathrm{Dm}$ mice. Error bars mark standard deviation. Six mice were analyzed in each group. Representative FACS plots can be seen in Figure S4 in Supplementary Material. mice was assessed. Here too, the proportion of mutations on the $\Delta \mathrm{Dm}$ allele was lower than on the WT allele (Figure 5C). As a control, a similar number of colonies were sequenced from $\mathrm{B}_{22}{ }^{+} \mathrm{PNA}^{\text {low }}$ cells, with no mutations detected (data not shown). While the average number of mutations is lower in the $\Delta \mathrm{Dm}$ allele, sequences which have undergone SHM do so at an efficiency similar to the WT allele, as seen when examining the mutation rate in total sequences versus rate in mutated sequences (Figure 5), suggesting that the Dm element affects the recruitment but not the processivity of the machinery involved in SHM. These results indicate that the Dm element, which is immediately adjacent to the intronic MAR and iEk, helps promote SHM. This is particularly notable, as deletion of the MAR/iEk region on its own has no discernable effect on the normal SHM process (18). Our results clearly show that the Dm element contributes to proper SHM at the Igк locus, a role which has not been previously attributed to the intronic enhancer region.

\section{DISCUSSION}

In this paper, we characterized a novel cis regulatory element sit-

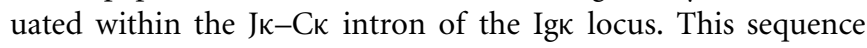
was originally identified as an element which lies adjacent to iEk and contributes to its demethylating activity, as deletion of either element was sufficient to abolish demethylation in a cell culture system (32). In our present study, we find that the Dm element is necessary for hypomethylation of the Igк locus of the Lк transgene in vivo, but is dispensable for the demethylation of the endogenous locus. The apparent discrepancy between the phenotype in these two cases may be due to the fact that the transgene contains the sequences in the Igк locus up to the $3^{\prime} \mathrm{E}$, but does not include the Ed. The three Igא enhancers work cooperatively and, to a certain extent, redundantly to activate and demethylate the locus. Previous studies have shown that deletion of any single enhancer has only a small effect on the developmentally regulated DNA demethylation, whereas the combined lack of two enhancers abolishes the demethylation process $(16,19)$. Another difference between the transgene and the endogenous locus is that the transgene contains a pre-rearranged Igк. It is possible that the Dm element only affects the demethylation when the locus is in a rearranged configuration, but not in the germline conformation. In this study, we see that the deletion of the Dm sequence, which is not part of the core $\mathrm{iE \kappa}$, greatly impedes the demethylation process in the transgene, indicating that the Dm element contributes to the activity of $\mathrm{iE \kappa}$, possibly as a co-enhancer. As the Dm is only a weak transcriptional enhancer as a solitary element, it is the combined activity with neighboring cis acting elements which gives rise to the full activity.

The mechanisms by which genomic loci undergo targeted demethylation have long been shrouded in mystery (40). Findings from recent years have pointed to the Tet family of enzymes as 

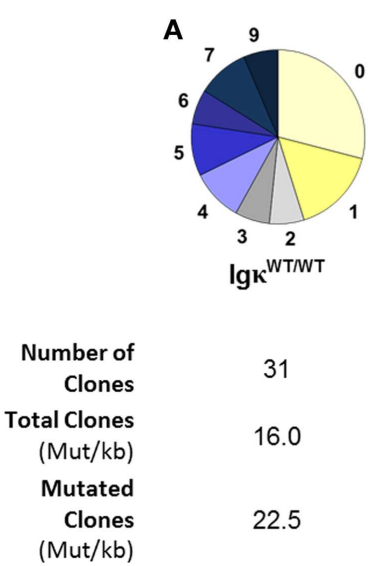

FIGURE 5 | Effect of deletion of the Dm element at the endogenous locus on somatic hypermutations. Somatic hypermutations in B220 ${ }^{+} N^{\text {high }}$ Peyer's patches germinal center B cells from (A) $\lg \kappa^{\mathrm{WT} / \mathrm{NT}}$, (B) $\lg \kappa^{\Delta \mathrm{Dm} / \Delta \mathrm{Dm}}$, and (C) $\lg \kappa^{\mathrm{WT} / \Delta \mathrm{Dm}}$ mice. Pie charts

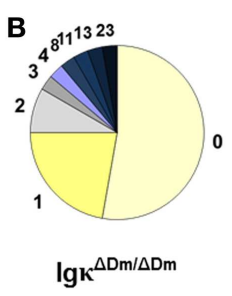

36

11.2

23.8

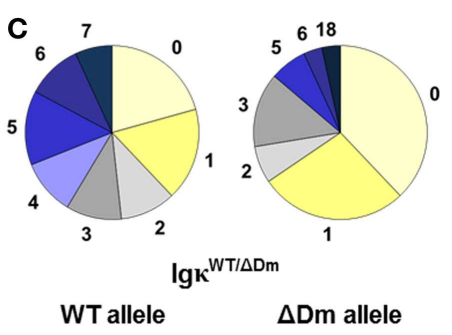

29

15.4

19.4
10.6

29

17.1 possible catalysts of the demethylation process, via oxidation of the methyl group into a hydroxymethyl moiety (41). When acting as a demethylation intermediate, the hydroxymethylated cytosine is then either passively diluted during DNA replication (42), as it is not recognized by the methylation maintenance machinery (43, 44 ), or, conversely, is actively excised from the genome and replaced with an unmethylated nucleotide $(45,46)$. Targeting of Tet proteins to specific genomic loci is sufficient to induce local demethylation $(47,48)$. Tet 2 has been implicated in the active demethylation of tissue-specific genes in postmitotic human monocytes (49). Additionally, Tet2 has been found to bind PU.1 (50) and EBF1 (51) in the hematopoietic system. A recent report has uncovered a different strategy to induce demethylation by which DNMT1, the maintenance DNA methyltransferase, is sequestered from specific genomic loci by binding non-coding RNA. This prevents the placement of methyl groups on DNA during replication and, in turn, brings about passive demethylation of a defined region (52). It is still unclear what mechanism is implemented by the cis regulatory elements to demethylate the Igк locus during B cell development, especially since deletion of Tet 2 , the strongest Tet candidate in the immune system, causes leukemia in mice (53-55), which masks many of the tissue-specific effects that may occur as a result. As methylation is a strong barrier to the rearrangement process (8), future studies can address this issue.

We have identified a sequence within the Dm element which binds the $\mathrm{B}$ cell lineage specifier Pax5. This site is bound by Pax 5 starting with the pre-B cell stage, up to mature B cells, but is unbound in Baf3 pro-B cells, where the Igк locus is not yet activated and made accessible for rearrangement, nor in plasma cells where Pax5 expression is down-regulated. It should be noted, though, that the Baf3 pro-B cell line tested here does not express Pax5 (56), whereas most pro-B cells do, and as such we are unable to rule out the possibility that Pax5 is already bound at the pro-B cell stage. This is the first report, to our knowledge, of a Pax5-binding site within the Igк locus which binds Pax5 at the time of locus activation. Previous reports have located sites in $3^{\prime}$ Ек (24) and indicate the number of mutations sequenced in a 188-bp region immediately downstream of the $V_{\kappa}-J_{\kappa} 5$ joint. Number of colonies sequenced from each mouse and mutation rate per kilobase in total and mutated clones are indicated. in the K-I-K-II $(29,30)$ regulatory elements in which Pax5 plays a repressive role and where binding is lost upon Igк locus activation. The new site we report is particularly interesting, considering that Pax5 is known to be directly necessary for Igk locus activation and $\kappa_{0}$ germline transcription in pre-B cells (31). We find that Pax5-binding in the vicinity of the $\mathrm{J} \kappa-$ Ск intron is dependent on the presence of the Dm element and that the Pax5-binding site contributes to the demethylating capabilities of the Dm element. While this clearly cannot be the only Pax5-binding site, since $\Delta \mathrm{Dm}$ pre-B cells maintain their full ability to rearrange the Igא locus, this site highlights the potency of this $\mathrm{B}$ cell identity protein in one more area of B cell development.

It should be noted that the sequence of the Pax5-binding site within the Dm element is conserved among rodents, but not in the human-Igк locus, though other aspects, such as the CpG-dense region, are. This is not the only aspect which differs between the human and murine counterparts of the Igк locus. For example, the Sis element, a transcriptional silencer which has been shown to recruit the Igк locus to the pericentromeric heterochromatin in mice, is not conserved in the human locus (57). It stands to reason that regulation of the human and murine Igк loci may differ somewhat, as the strongly biased usage of the $\kappa$ versus $\lambda$ chain seen in mice (where $95 \%$ of mature B cells express the $\kappa$ chain) is not present in humans, which have a ratio of 60:40 of $\kappa$ versus $\lambda$ usage (58). This could be due to differences in the RR of the human and murine Igk locus that may contribute to this phenomenon.

While the deletion of the Dm element did not, on its own, affect the methylation status of the endogenous Igк locus, nor the relative amount of the deleted allele which underwent rearrangement, we observed a decrease in the levels of SHM on Igк alleles lacking the Dm element. The role of the Dm element in facilitating SHM appears to be independent of the iЕк/MAR region, since the combined deletion of the iEк and MAR elements has no perceptible effect on SHM (18). The lower level of SHM does not appear to be the result of lower levels of Igא transcription, since deletion of the Dm element does not lower the levels of Igк RNA 
observed in mature B cells. Deletion of the Dm element appears to cause inefficient recruitment of the mutating machinery, but once the machinery is in place, the mutation efficiency is similar to the WT locus. The element may therefore function by efficiently recruiting the mutation machinery to the locus, possibly by key regulators such as Pax 5 which are bound to the Dm element. Pax5 itself has a known role in SHM by activating the transcription of the Aicda gene, encoding the AID protein, which is the deaminase responsible for $\operatorname{SHM}(59,60)$. It may be that Pax 5 plays more than one role in SHM induction. The role of the Dm element in SHM fits in well with its location, which is almost immediately adjacent to the $\mathrm{V} \kappa-\mathrm{J} \kappa$ rearranged region which is the hotspot for SHM.

In conclusion, we have characterized the Dm sequence as an element that regulates the Igא locus during different stages of B cell development. The Dm is both a team player, cooperating with the three characterized enhancers to demethylate the locus for rearrangement, as well as an element that affects the locus in its own right in allowing efficient SHM. This report adds to our understanding of the complex regulation of the Igк locus, which undergoes many drastic changes during development and must be fine-tuned for each developmental stage.

\section{AUTHOR CONTRIBUTIONS}

Rena Levin-Klein, Andrei Kirillov, and Chaggai Rosenbluh designed the experiments, did the research, and interpreted the results. Howard Cedar and Yehudit Bergman directed the study. Rena Levin-Klein and Yehudit Bergman wrote the manuscript.

\section{ACKNOWLEDGMENTS}

We would like to thank Prof. Meinrad Busslinger for providing antibodies, Pax5 expression vector, and his scientific expertise regarding Pax5, Prof. Michael Neuberger for providing the original

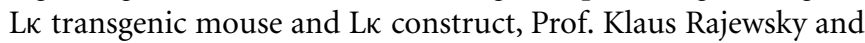
Dr. Raul Mostoslavsky for assistance in generating Igא $\kappa^{\Delta \mathrm{Dm}}$ mice, Gidon Toperoff for assistance with Pyrosequencing, and Adam Spiro for assistance with bioinformatics analysis. This work was supported by research grants from the Israel Academy of Sciences (Howard Cedar, Yehudit Bergman), NIH (Yehudit Bergman), the Israel Cancer Research Foundation (Howard Cedar, Yehudit Bergman), and the USA-Israel Binational Science Foundation (Yehudit Bergman).

\section{SUPPLEMENTARY MATERIAL}

The Supplementary Material for this article can be found online at http://www.frontiersin.org/journal/10.3389/fimmu.2014.00240/ abstract

\section{REFERENCES}

1. Gellert M. V(D)J recombination: RAG proteins, repair factors, and regulation. Annu Rev Biochem (2002) 71:101-32. doi:10.1146/annurev.biochem.71.090501. 150203

2. Yancopoulos GD, Alt FW. Developmentally controlled and tissue-specific expression of unrearranged VH gene segments. Cell (1985) 40(2):271-81. doi:10.1016/ 0092-8674(85)90141-2

3. Constantinescu A, Schlissel MS. Changes in locus-specific V(D)J recombinase activity induced by immunoglobulin gene products during $\mathrm{B}$ cell development. J Exp Med (1997) 185(4):609-20. doi:10.1084/jem.185.4.609
4. Stanhope-Baker P, Hudson KM, Shaffer AL, Constantinescu A, Schlissel MS. Cell type-specific chromatin structure determines the targeting of $\mathrm{V}(\mathrm{D}) \mathrm{J}$ recombinase activity in vitro. Cell (1996) 85(6):887-97. doi:10.1016/S0092-8674(00) 81272-6

5. Mostoslavsky R, Singh N, Kirillov A, Pelanda R, Cedar H, Chess A, et al. Kappa chain monoallelic demethylation and the establishment of allelic exclusion. Genes Dev (1998) 12(12):1801-11. doi:10.1101/gad.12.12.1801

6. Nakase H, Takahama Y, Akamatsu Y. Effect of CpG methylation on RAG1/RAG2 reactivity: implications of direct and indirect mechanisms for controlling V(D)J cleavage. EMBO Rep (2003) 4(8):774-80. doi:10.1038/sj.embor.embor904

7. Goldmit M, Ji Y, Skok J, Roldan E, Jung S, Cedar H, et al. Epigenetic ontogeny of the Igk locus during B cell development. Nat Immunol (2005) 6(2):198-203. doi:10.1038/ni1 154

8. Goldmit M, Schlissel M, Cedar H, Bergman Y. Differential accessibility at the kappa chain locus plays a role in allelic exclusion. EMBO J (2002) 21(19):5255-61. doi:10.1093/emboj/cdf518

9. Odegard VH, Schatz DG. Targeting of somatic hypermutation. Nat Rev Immunol (2006) 6(8):573-83. doi:10.1038/nri1896

10. Fraenkel S, Mostoslavsky R, Novobrantseva TI, Pelanda R, Chaudhuri J, Esposito G, et al. Allelic 'choice' governs somatic hypermutation in vivo at the immunoglobulin kappa-chain locus. Nat Immunol (2007) 8(7):715-22. doi:10.1038/nil476

11. Queen C, Baltimore D. Immunoglobulin gene transcription is activated by downstream sequence elements. Cell (1983) 33(3):741-8. doi:10.1016/00928674(83)90016-8

12. Meyer KB, Neuberger MS. The immunoglobulin kappa locus contains a second, stronger B-cell-specific enhancer which is located downstream of the constant region. EMBO J (1989) 8(7):1959-64.

13. Liu ZM, George-Raizen JB, Li S, Meyers KC, Chang MY, Garrard WT. Chromatin structural analyses of the mouse Igkappa gene locus reveal new hypersensitive sites specifying a transcriptional silencer and enhancer. J Biol Chem (2002) 277(36):32640-9. doi:10.1074/jbc.M204065200

14. Xu Y, Davidson L, Alt FW, Baltimore D. Deletion of the Ig kappa light chain intronic enhancer/matrix attachment region impairs but does not abolish $\mathrm{V}$ kappa J kappa rearrangement. Immunity (1996) 4(4):377-85. doi:10.1016/ S1074-7613(00)80251-4

15. Gorman JR, van der Stoep N, Monroe R, Cogne M, Davidson L, Alt FW. The $\operatorname{Ig}($ kappa $)$ enhancer influences the ratio of $\operatorname{Ig}($ kappa) versus $\operatorname{Ig}$ (lambda) B lymphocytes. Immunity (1996) 5(3):241-52. doi:10.1016/S1074-7613(00)80319-2

16. Inlay M, Alt FW, Baltimore D, Xu Y. Essential roles of the kappa light chain intronic enhancer and $3^{\prime}$ enhancer in kappa rearrangement and demethylation. Nat Immunol (2002) 3(5):463-8. doi:10.1038/ni790

17. Xiang Y, Garrard WT. The Downstream Transcriptional Enhancer, Ed, positively regulates mouse Ig kappa gene expression and somatic hypermutation. $J$ Immunol (2008) 180(10):6725-32. doi:10.4049/jimmunol.180.10.6725

18. Inlay MA, Gao HH, Odegard VH, Lin T, Schatz DG, Xu Y. Roles of the Ig kappa light chain intronic and $3^{\prime}$ enhancers in Igk somatic hypermutation. J Immunol (2006) 177(2):1146-51. doi:10.4049/jimmunol.177.2.1146

19. Zhou X, Xiang Y, Garrard WT. The Igkappa gene enhancers, E3' and Ed, are essential for triggering transcription. J Immunol (2010) 185(12):7544-52. doi:10.4049/jimmunol.1002665

20. Inlay MA, Lin T, Gao HH, Xu Y. Critical roles of the immunoglobulin intronic enhancers in maintaining the sequential rearrangement of $\operatorname{IgH}$ and Igk loci. J Exp Med (2006) 203(7):1721-32. doi:10.1084/jem.20052310

21. Zhou X, Xiang Y, Ding X, Garrard WT. A new hypersensitive site, HS10, and the enhancers, E3 ${ }^{\prime}$ and Ed, differentially regulate Igkappa gene expression. JImmunol (2012) 188(6):2722-32. doi:10.4049/jimmunol.1102758

22. Cockerill PN, Garrard WT. Chromosomal loop anchorage of the kappa immunoglobulin gene occurs next to the enhancer in a region containing topoisomerase II sites. Cell (1986) 44(2):273-82. doi:10.1016/0092-8674(86)90761-0

23. McDevit DC, Perkins L, Atchison ML, Nikolajczyk BS. The Ig kappa $3^{\prime}$ enhancer is activated by gradients of chromatin accessibility and protein association. J Immunol (2005) 174(5):2834-42. doi:10.4049/jimmunol.174.5.2834

24. Shaffer AL, Peng A, Schlissel MS. In vivo occupancy of the kappa light chain enhancers in primary pro- and pre-B cells: a model for kappa locus activation. Immunity (1997) 6(2):131-43. doi:10.1016/S1074-7613(00)80420-3

25. Roque MC, Smith PA, Blasquez VC. A developmentally modulated chromatin structure at the mouse immunoglobulin kappa $3^{\prime}$ enhancer. Mol Cell Biol (1996) 16(6):3138-55. 
26. Lazorchak AS, Schlissel MS, Zhuang Y. E2A and IRF-4/Pip promote chromatin modification and transcription of the immunoglobulin kappa locus in pre-B cells. Mol Cell Biol (2006) 26(3):810-21. doi:10.1128/MCB.26.3.810-821. 2006

27. Inlay MA, Tian $\mathrm{H}$, Lin $\mathrm{T}, \mathrm{Xu} \mathrm{Y}$. Important roles for $\mathrm{E}$ protein binding sites within the immunoglobulin kappa chain intronic enhancer in activating Vkappa Jkappa rearrangement. J Exp Med (2004) 200(9):1205-11. doi:10.1084/jem. 20041135

28. Maitra S, Atchison M. BSAP can repress enhancer activity by targeting PU.1 function. Mol Cell Biol (2000) 20(6):1911-22. doi:10.1128/MCB.20.6.1911-1922. 2000

29. Sato H, Wang D, Kudo A. Dissociation of Pax-5 from KI and KII sites during kappa-chain gene rearrangement correlates with its association with the underphosphorylated form of retinoblastoma. J Immunol (2001) 166(11):6704-10. doi:10.4049/jimmunol.166.11.6704

30. Tian J, Okabe T, Miyazaki T, Takeshita S, Kudo A. Pax-5 is identical to EBB$1 / \mathrm{KLP}$ and binds to the VpreB and lambda5 promoters as well as the KI and KII sites upstream of the Jkappa genes. Eur J Immunol (1997) 27(3):750-5. doi:10.1002/eji.1830270325

31. Sato H, Saito-Ohara F, Inazawa J, Kudo A. Pax-5 is essential for kappa sterile transcription during Ig kappa chain gene rearrangement. J Immunol (2004) 172(8):4858-65. doi:10.4049/jimmunol.172.8.4858

32. Lichtenstein M, Keini G, Cedar H, Bergman Y. B cell-specific demethylation: a novel role for the intronic kappa chain enhancer sequence. Cell (1994) 76(5):913-23. doi:10.1016/0092-8674(94)90365-4

33. Casellas R, Shih TA, Kleinewietfeld M, Rakonjac J, Nemazee D, Rajewsky K, et al. Contribution of receptor editing to the antibody repertoire. Science (2001) 291(5508):1541-4. doi:10.1126/science. 1056600

34. Meyer KB, Sharpe MJ, Surani MA, Neuberger MS. The importance of the $3^{\prime}$ enhancer region in immunoglobulin kappa gene expression. Nucleic Acids Res (1990) 18(19):5609-15. doi:10.1093/nar/18.19.5609

35. Farago M, Rosenbluh C, Tevlin M, Fraenkel S, Schlesinger S, Masika H, et al. Clonal allelic predetermination of immunoglobulin-kappa rearrangement. Nature (2012) 490(7421):561-5. doi:10.1038/nature11496

36. Gulick T. Transfection using DEAE-dextran. Curr Protoc Cell Biol (2003) Chapter 20:Unit20.4. doi:10.1002/0471143030.cb2004s19

37. Southern EM. Detection of specific sequences among DNA fragments separated by gel electrophoresis. J Mol Biol (1975) 98(3):503-17. doi:10.1016/S00222836(75)80083-0

38. Czerny T, Schaffner G, Busslinger M. DNA sequence recognition by Pax proteins: bipartite structure of the paired domain and its binding site. Genes Dev (1993) 7(10):2048-61. doi:10.1101/gad.7.10.2048

39. Sharpe MJ, Milstein C, Jarvis JM, Neuberger MS. Somatic hypermutation of immunoglobulin kappa may depend on sequences $3^{\prime}$ of $C$ kappa and occurs on passenger transgenes. EMBO J (1991) 10(8):2139-45.

40. Ooi SK, Bestor TH. The colorful history of active DNA demethylation. Cell (2008) 133(7):1145-8. doi:10.1016/j.cell.2008.06.009

41. Tahiliani M, Koh KP, Shen Y, Pastor WA, Bandukwala H, Brudno Y, et al. Conversion of 5-methylcytosine to 5-hydroxymethylcytosine in mammalian DNA by MLL partner TET1. Science (2009) 324(5929):930-5. doi:10.1126/science. 1170116

42. Inoue A, Zhang Y. Replication-dependent loss of 5-hydroxymethylcytosine in mouse preimplantation embryos. Science (2011) 334(6053):194. doi:10.1126/ science. 1212483

43. Hashimoto H, Liu Y, Upadhyay AK, Chang Y, Howerton SB, Vertino PM, et al. Recognition and potential mechanisms for replication and erasure of cytosine hydroxymethylation. Nucleic Acids Res (2012) 40(11):4841-9. doi:10.1093/nar/ gks155

44. Otani J, Kimura H, Sharif J, Endo TA, Mishima Y, Kawakami T, et al. Cell cycle-dependent turnover of 5-hydroxymethyl cytosine in mouse embryonic stem cells. PLoS One (2013) 8(12):e82961. doi:10.1371/journal.pone. 0082961

45. Guo JU, Su Y, Zhong C, Ming GL, Song H. Hydroxylation of 5-methylcytosine by TET1 promotes active DNA demethylation in the adult brain. Cell (2011) 145(3):423-34. doi:10.1016/j.cell.2011.03.022

46. He YF, Li BZ, Li Z, Liu P, Wang Y, Tang Q, et al. Tet-mediated formation of 5carboxylcytosine and its excision by TDG in mammalian DNA. Science (2011) 333(6047):1303-7. doi:10.1126/science.1210944
47. Maeder ML, Angstman JF, Richardson ME, Linder SJ, Cascio VM, Tsai SQ, et al. Targeted DNA demethylation and activation of endogenous genes using programmable TALE-TET1 fusion proteins. Nat Biotechnol (2013) 31(12):1137-42. doi: $10.1038 /$ nbt.2726

48. Chen H, Kazemier HG, de Groote ML, Ruiters MH, Xu GL, Rots MG. Induced DNA demethylation by targeting ten-eleven translocation 2 to the human ICAM-1 promoter. Nucleic Acids Res (2014) 42(3):1563-74. doi:10.1093/nar/ gkt1019

49. Klug M, Schmidhofer S, Gebhard C, Andreesen R, Rehli M. 5Hydroxymethylcytosine is an essential intermediate of active DNA demethylation processes in primary human monocytes. Genome Biol (2013) 14(5):R46. doi:10.1186/gb-2013-14-5-r46

50. de la Rica L, Rodriguez-Ubreva J, Garcia M, Islam AB, Urquiza JM, Hernando $\mathrm{H}$, et al. PU.1 target genes undergo Tet2-coupled demethylation and DNMT3bmediated methylation in monocyte-to-osteoclast differentiation. Genome Biol (2013) 14(9):R99. doi:10.1186/gb-2013-14-9-r99

51. Guilhamon P, Eskandarpour M, Halai D, Wilson GA, Feber A, Teschendorff AE, et al. Meta-analysis of IDH-mutant cancers identifies EBF1 as an interaction partner for TET2. Nat Commun (2013) 4:2166. doi:10.1038/ncomms3166

52. Di Ruscio A, Ebralidze AK, Benoukraf T, Amabile G, Goff LA, Terragni J, et al. DNMT1-interacting RNAs block gene-specific DNA methylation. Nature (2013) 503(7476):371-6. doi:10.1038/nature12598

53. Ko M, Bandukwala HS, An J, Lamperti ED, Thompson EC, Hastie R, et al. Teneleven-translocation 2 (TET2) negatively regulates homeostasis and differentiation of hematopoietic stem cells in mice. Proc Natl Acad Sci U S A (2011) 108(35):14566-71. doi:10.1073/pnas.1112317108

54. Li Z, Cai X, Cai CL, Wang J, Zhang W, Petersen BE, et al. Deletion of Tet2 in mice leads to dysregulated hematopoietic stem cells and subsequent development of myeloid malignancies. Blood (2011) 118(17):4509-18. doi:10.1182/blood2010-12-325241

55. Moran-Crusio K, Reavie L, Shih A, Abdel-Wahab O, Ndiaye-Lobry D, Lobry $\mathrm{C}$, et al. Tet2 loss leads to increased hematopoietic stem cell self-renewal and myeloid transformation. Cancer Cell (2011) 20(1):11-24. doi:10.1016/j.ccr. 2011.06.001

56. Sigvardsson M, Clark DR, Fitzsimmons D, Doyle M, Akerblad P, Breslin T, et al. Early B-cell factor, E2A, and Pax- 5 cooperate to activate the early B cell-specific mb-1 promoter. Mol Cell Biol (2002) 22(24):8539-51. doi:10.1128/MCB.22.24. 8539-8551.2002

57. Liu Z, Widlak P, Zou Y, Xiao F, Oh M, Li S, et al. A recombination silencer that specifies heterochromatin positioning and ikaros association in the immunoglobulin kappa locus. Immunity (2006) 24(4):405-15. doi:10.1016/j. immuni.2006.02.001

58. Popov AV, Zou X, Xian J, Nicholson IC, Bruggemann M. A human immunoglobulin lambda locus is similarly well expressed in mice and humans. J Exp Med (1999) 189(10):1611-20. doi:10.1084/jem.189.10.1611

59. Gonda H, Sugai M, Nambu Y, Katakai T, Agata Y, Mori KJ, et al. The balance between Pax 5 and Id 2 activities is the key to AID gene expression. J Exp Med (2003) 198(9):1427-37. doi:10.1084/jem.20030802

60. Tran TH, Nakata M, Suzuki K, Begum NA, Shinkura R, Fagarasan S, et al. B cellspecific and stimulation-responsive enhancers derepress Aicda by overcoming the effects of silencers. Nat Immunol (2010) 11(2):148-54. doi:10.1038/ni.1829

Conflict of Interest Statement: The authors declare that the research was conducted in the absence of any commercial or financial relationships that could be construed as a potential conflict of interest.

Received: 28 January 2014; accepted: 08 May 2014; published online: 23 May 2014. Citation: Levin-Klein R, Kirillov A, Rosenbluh C, Cedar H and Bergman Y (2014) A novel Pax5-binding regulatory element in the Igא locus. Front. Immunol. 5:240. doi: 10.3389/fimmu.2014.00240

This article was submitted to B Cell Biology, a section of the journal Frontiers in Immunology.

Copyright (C) 2014 Levin-Klein, Kirillov, Rosenbluh, Cedar and Bergman. This is an open-access article distributed under the terms of the Creative Commons Attribution License (CC BY). The use, distribution or reproduction in other forums is permitted, provided the original author(s) or licensor are credited and that the original publication in this journal is cited, in accordance with accepted academic practice. No use, distribution or reproduction is permitted which does not comply with these terms. 